\title{
TIME HAS GONE TODAY
}

\author{
Frank A. PIONTEK, \\ M.A., 18855 Waite Blvd. South Bend, Indiana, USA. \\ Email: frankpiontek@sbcglobal.net
}

\begin{abstract}
This essay proposes to address features of Time in Science and Philosophy then emphasize those findings in reference to Philosophical Theology, predominately in Theodicy. Those disciplines all have produced a number of longstanding and contrasting viewpoints regarding Time. Positions will be presented to emphasize incongruent standpoints in those disciplines to substantiate the concept that a new Philosophy of Time is needed and how that thinking impacts our understanding of the problem of evil or Theodicy. The predominant linear view of time obfuscates our understanding of Time and Evil. The Platonic concept of anamnesis is amended here as the preeminent concept of Time and also how Time as anamnesis pertains to Omniscience and the problem of evil. Time flows backwards not forwards. We are already completed but we unfurl in Time because we have forgotten how we freely chose ourselves. Omniscience knows this; we don't remember and now live that forgetfulness. A Book of Life is written, we cannot recall our page number..
\end{abstract}

Keywords: Philosophy of Time; Philosophy of Science; Metaphysics; Theodicy;

\section{INTRODUCTION}

There are a number of longstanding incongruences found in the Philosophy of Time. There are a number of longstanding incongruences found when studying the problem of evil. Inge adjoins that excepting the problem of evil, Time is the hardest in all of philosophy ${ }^{1}$. Time is also thought to be the most disconcerting of all the obstacles to a thoroughly penetrating account of existence; as the mathematical physicist Weyl says "Explain time? Not without explaining existence. Explain existence? Not without explaining time"2.

Others contend that cosmology relates to theology while developing in time ${ }^{3}$ and that there is a profound connection between the philosophy of time, cosmology, and metaphysics ${ }^{4}$. Still others see that the theoretical edifice of science is not very different from that of theology $y^{5}$ and that there is an intensification of the dialogue between science and religion ${ }^{6}$.

Some maintain current generally accepted ontological views are consistent with time in modern science ${ }^{7}$.Others counter that the epistemological status of many of those views are far from established, highly speculative or not even addressed ${ }^{8}$. For Plank, science cannot solve the ultimate mystery of nature; because we are part of nature and therefore part of the mystery we are trying to solve ${ }^{9}$. Yet, Reichenbach states that if there is a solution to the philosophical problem of Time, it is written down in the equations of mathematical physics ${ }^{10}$. However, mathematics (and its implications for physics) have been shown by Gödel to lack final systemization and are not free from internal contradiction ${ }^{11}$. By using pure logic alone, 
it is impossible to refute anyone claiming the universe was created an hour ago ${ }^{12}$. Hence "physics has no far-reaching meaning for reality, just as formal logic, for example, has no far-reaching meaning in the realm of truth" ${ }^{\prime 13}$. Time, it appears has as many different meanings as there are theoretical frameworks for doing physics ${ }^{14}$.

Yet the most common scientific strategy is to avoid the how and why of cosmology, metaphysics and Time and turn to language, or logic and to the structures of texts ${ }^{15}$. Thus, some maintain a metaphysical chasm persists between science and theology ${ }^{16}$; while Rahner thinks the sciences have or are close to replacing philosophy as a key theology partner ${ }^{17}$. It seems the considerations of Time and Theology are still in the eye of the beholder.

\section{SO WHAT TIME IS IT?}

The orthodox view of Time, from Boethius to the present day, has been typically seen from the present into the past and projected into the future ${ }^{18}$. Many hold this arrow of time as the primary, objective reality in a linear orientation towards the future ${ }^{19}$. Christianity, Islam and Judaism all have such a deeply linear view of time ${ }^{20}$. Swinburne ${ }^{21}$ also agrees that Time is linear. Bergson's view of Time as duration is also linear ${ }^{22}$. The linear view of Time, also called the asymmetry of time never changes its direction of flow and is a psychological time, which each of us \{presumably (mine) $\}$ experiences as a present moment moving to the future ${ }^{23}$.

Evolution science also purports there can be only a linear view of time since natural selection cannot work with any "illusory" arrows of time; so if natural selection cannot work, then empirical science is orphaned ${ }^{24}$. Yet during most of the timeframes through which the very small evolutionary variations occur; no advantage has been gained nor any reason why such were preserved by "natural selection" 25 . Natural selection is a tautology in explanation, since it always must look backward; it assumes linearity and is unable to predict its own impending course and thus is blind to what will happen in the future ${ }^{26}$. Evolution also presupposes a theatre within which natural selection takes place ${ }^{27}$. Dawkins takes for granted the existence of physio-chemical material that "is a precondition of the possibility of evolution"; hence evolution cannot explain its own existence ${ }^{28}$. Its' arrow of time is not at all posited as a basic law of physics; where equations do not specify a unique direction of time ${ }^{29}$ and thus consequently controverts evolution ${ }^{30}$.Quantum theory further denies all meaning to the notions of before and after in the world of the very small so: "Time is in trouble" 31 . The stubbornly persistent illusion between past, present and future from Einstein ${ }^{32}$ remains. And so, what Time is it?

Divergent positions regarding Time, its theoretical approach and views presented from science were shown to emphasize and substantiate the concept that a new or different philosophy of time is needed. Perhaps it is now time for Time to be brought to light ${ }^{33}$.

\section{TIME AND TIME AGAIN IN PHILOSOPHY:}

That Number is Time was a tenet of Greek philosophy from Plato \& Aristotle onwards $^{34}$. Aristotle explores if Time exists or not and what sort of movement it is ${ }^{35}$. Plato asserted that time imitates eternity and "is" stands as an inaccurate expression regarding some modes of time ${ }^{36}$; while any learning whatsoever is recollection ${ }^{37}$ while any knowledge can be known only through that recollection which comes from anamnesis ${ }^{38}$. From McTaggert we have the unreality of time ${ }^{39}$ and also the A, B, C's of Time ${ }^{40}$. Rogers asks if the future exists now or not ${ }^{41}$. Sprigge, like Einstein, contends that the contrast between pastpresent-future is less than it seems ${ }^{42}$. Or is it that the becoming of us and the becoming of 
time are the same thing: decoherence ${ }^{43}$. Then again, McTaggart adds Spinoza, Kant, Schopenhauer, Bradley and almost all mysticism to the illusion of time school ${ }^{44}$. Yet a nihilist counterpart to any mysticism, Time from Meillassoux, is capable of destroying becoming itself and bringing forth death ${ }^{45}$. Heidegger asks who is Time and presupposes that Time is a being or entity ${ }^{46}$. Rahner also looked at Time as a creation ${ }^{47}$. Augustine stated we cannot truly say that time is, because it tends not to $b^{48}$. Hegel proposed time as that being which, in as much as it is, is not, and in as much as it is not is ${ }^{49}$. Numerous thinkers posit the future of Time as prominent. Plotinus contended that what exists potentially proceeds from what later is actual ${ }^{50}$. Von Bertalanffy portrays a philosophy of Nicolas of Cusa, which relates that "whatever we do or think has been in us, i.e., latency" as only a "becoming" and should be credited to us exactly as if we were already in full possession of it (mine); to this we only have a capability of receiving",52. Schelling argued that the ruling dimension is the future; the time in time ${ }^{53}$. Heidegger states the past of Dasein is something that already goes ahead of it, often referencing its "futural" character".

Whitehead and Merleau-Ponty accept nature as an unfurling ${ }^{55}$. Rahner has the historicality of man unfolding (mine) towards a historical fulfillment ${ }^{56}$. McCall describes his branching view of time where all branching lies not in the past or present but exclusively and concretely in the future ${ }^{57}$. Augustine recalls how should I know forgetfulness if I did not remember it ${ }^{58}$ or he might call this remembering of our past "Illumination"

Whitehead also contends a general reference to "Beyond" in the event is a must to have any reference at all ${ }^{60}$. For Pannenberg; appearance is the arrival of the future; something moving more that it is as it presently appears to $\mathrm{me}^{61}$. Or that Time has two movements, procession and return; "the way forward is the way back, the way back is the way forward" 62 . For Wyle time awakens (mine) to a life one point one after another as a section of this world comes to life then passes like a picture (mine) ${ }^{63}$. To Leftow, "events occur in the frozen simultaneity of eternity, but also follow one another in time" 64 .

\section{THE TIMES?}

We have implied existence, which is implying or not implying time and whether time is an entity or a being. We have time in trouble, different, disconcerting, created, destructive, developing, assembled, designated, or just merely the measurement of the sensorium. We have the linear view of time, the psychological view of time, the illusion of time, the futural view of time or not, the non-nature of time, the decoherence view of time, the unfolding or not of time, the mystical view of time, and the unfurling and the unreality of time. We have Time as number, equation, latency, becoming, appearance, connected or avoided, awakened, eternal, frozen or only present; beyond ,branched, temporal, posited or not; unspecified or not, closed or not. Time is and is not; becoming or not, is not and is; is not yet but is no more. After Augustine, shall I ask the question; "What is time"

Given all these variations in the portrayals of Time; is it seems clear why Gödel suggested philosophers need to change their views of time ${ }^{66}$ ?

Additionally, if there is no such thing as time in the usual sense ${ }^{67}$; perhaps we need a new philosophy of time ${ }^{68}$ ? Moreover, Theology also needs a new direction ${ }^{69}$. Upon delivering a variety of similarly disparate views of Theodicy, another view of Time and the problem of evil will be presented. 


\section{THEODICY:}

One of the oldest and most venerable issues dealt with by philosophical theology is the problem of evil or theodicy, where God is omnipotent and perfectly good yet there is much evil in the world ${ }^{70}$.

Hume notes the old questions from Epicurus' are unanswered: "Is he willing to prevent evil and not able then he is impotent or is he willing to prevent evil and not willing than he is malevolent. Is he both able and willing, whence then is evil ${ }^{71}$ ? Thus a general purpose of a theodicy is to ascribe to God some reason that would morally justify his permission of the evil and suffering we find in our world ${ }^{72}$ while also addressing God's relationship to Time; since throughout the history of philosophy practically every philosopher has considered God's relationship to Time ${ }^{73}$. Views in Theodicy like those in the sciences regarding Time are diverse.

Ricoeur thought that the problem of evil drew philosophy to its own limit ${ }^{74}$.Some argue theodicy is possibly the least satisfactory area in theology ${ }^{75}$. Others investigating traditional defenses of God, note that if the road to hell is paved with good intentions, the road to heaven is paved with failed theodicies ${ }^{76}$. Kant eschews metaphysical questions of theodicy ${ }^{77}$. Whitehead's Theodicy denies Omnipotence, as God can only function as a persuasive agency ${ }^{78}$. Royce states we regret evil has "being",79. Swinburne says that lacking a theodicy, evil counts against the existence of $\operatorname{God}^{80}$; while the "escamotage" of Christian Theology is to solve the drama of divine justice ${ }^{81}$. To Sartre, the evils perpetrated in Auschwitz, Cambodia and the like are irredeemable ${ }^{82}$. Galbraith sets out Roth's anti-theodicy of God; who is "everlastingly guilty-where the degrees here run from gross negligence to murder ${ }^{83}$. Roth also calls it an irresponsible fact that God sets the boundaries of our life and being yet lives elsewhere ${ }^{84}$. Schellenberg declares "the weakness of evidence for theism is itself evidence against it, that is, why would God be hidden from us" ${ }^{85}$ ? Spinoza has evil rather imagined than real ${ }^{86}$; others that evil is an illusion ${ }^{87}$ or not $^{88}$.

We are also considered too immature to fathom horrendous evils ${ }^{89}$ (Adams 1990, 217). Then again, God is dead ${ }^{90}$ while Meillassoux proposes there is a nihilist counterpart to the hypothesis of an all powerful God which could also be maintained ${ }^{91}$.

It is also thought that the numerous theodical conditions found in that literature are all logically related to each other ${ }^{92}$. Here we see thirty two chapters of numerous and wide ranging positions and strategies regarding the problem of evil ${ }^{93}$. Most all of those chapters are elsewhere consolidated into twenty one major topics of Western solutions while Vedic, Brahamanic, Upanisadic and Bhagavad-Gita solutions from Indian sources addressing the problem of evil are also surveyed ${ }^{94}$. Additionally, we have two dozen or so theodical essays ${ }^{95}$ and six volumes in the philosophy of evil across classic cultures and times ${ }^{96}$. None of those comprehensive works or any of the previously presented futural views incorporates any view of Time as a solution to the problem of evil.

\section{Anamnestic Time and Theodicy:}

By accepting the predominant linear conception of time and our presumed and assumed psychological flow of time from the present into the future; we obfuscate our understanding of Time and also of evil.

Time is not marching on but is flowing backwards, not forwards. Time is an unfolding, a spooling back, a repeat; the unravelling and unwinding of our life in the Omniscient "DVD/Blue Ray". We think we have a linear view of Time but we are recollecting what we have lived, since we have forgotten it. Time is that DVD evidence; the 
record of what we have volitionally done; the logical and natural consequences from our anamnestic view of now.

Omniscience knows this, we forgot, and now experience that anamnesis here, remembered from there. Before the world begins and before being unfolds- God defines God individually to all- a Subject that none are free to avoid ${ }^{97}$. Yet we try and blame God. We are already complete yet we forgot how we did it; so we live and recall it. God is wholly present to every point in time; which is immediately present to $\operatorname{God}^{98}$ but, significantly, not to us. Time reveals what we did, how we did it and why we did it as we become unhidden from ourselves in a Time prior to Time.

\section{DIVINE NONOMNISCIENCE, ANAMNESTIC TIME AND FREE WILL:}

Several ideas surround the proposal of free will which humanity used to vacate itself from Goodness. Leibniz argued that "God could not give the creature all without making of it a God"99. Caputo asserts that God as creator was working with elements that signified a certain limit on Gods power ${ }^{100}$. Bugiulescu stresses that man is the only being created by God who has the ability be like his Creator ${ }^{101}$ while "being free from the boundaries imposed by His nature" 102 . Plantinga argues "Omnipotence cannot create free creatures to initiate the possibility of moral evil while simultaneously prohibiting its actuality" ${ }^{\prime 03}$. Choo and Goh recently defended objections to Plantinga's argument for Free Will and then extended them ${ }^{104}$. Real freedom says Rahner "must include the possibility of rejecting God"105. So we chose the non-Good and rejected God.

The logical consequences of our choosing not-God were shown to us instantaneously with our rejection of the Good. All creation occurred all at once ${ }^{106}$; as everything God does, God does in a single act; all at once"107. From a "God's eye view, the whole of time exists, there is no passing moment called the present"108. Creation and the end thereof thus occurred simultaneously. God knows all that He ever knows; including events that to us are future; as our lives are played out (mine) ${ }^{109}$. Thus, from God's perspective, our DVD was "being" rewound for us; showing ourselves to ourselves in what has been called the eschatological moment ${ }^{110}$. Our Film started rewinding immediately at our mistaken selection, as we are shown the consequences of our free choice of God rejection; individually, throughout Time; not unlike the story of the Descent as a symbolic turning away from God into the self ${ }^{111}$.

We chose very badly and forgot and continue on with very bad choices and forget. As a result, the Realm before the choice was and is now no longer. We are our own unknown happenings in the estachological moment; now recalling how we got there. Our limited frame of reference often seems to be the "present"; much like many previously displayed views of Time. Some of those views of Time were futural in scope yet none proposed the anamnestic view of Time where the forgotten eschatological moment is the frame of reference.

All is past and is not, but is: while we do not recall our chosen choice. That choice was simultaneously presented at the eschatological moment, now anamnestically lived. We forget that Time is the replay of Divine Justice, showing us the lack of our implementation of it; displaying the free willed rejection of God to ourselves. So how is God responsible for our free actions to choose the non-Good; or evil, without making us automatons?

But to Phillips, such a free will defense position to evil cannot be left to God's creation of free beings where from that freedom alone "everything thereafter is their responsibility" "112. Why not? The ramifications of that freedom to reject God must be proportional to the act of rejection. The "thereafters" from Phillips are logical consequences 
from the rejected Good. In what kingdom do you give up, renunciate or otherwise renounce your citizenship and then expect to be protected by that rejected realm? Is denaturalization; where the chosen loss of citizenship is enacted by a kingdom dishonest, unlawful or prohibited? Evil is that which ought not to be and exists as only an infringement or opposition to an Ideal ${ }^{13}$; and a very rejected and infringed upon Ideal at that.

Rejecting Goodness is not unlike what Hunt clearly describes as the consequences of accidental necessity where conditions that are not necessary (since they could have turned out differently) having once occurred, limit what going forward is possible. The stone didn't have to be thrown into the water but was and nothing can be done to prevent the ensuing ripples ${ }^{114}$. We recall the options to throw or not, threw and did not like the waves. We would like to erase the picture, disregard, and ignore that which we did as it is being recalled from the existing finality.

The Anamnestic Theodicy presented here addresses the previously exhibited issues like the "escamotage" and the related drama surrounding the "guilt" and "irredeemable" nonsense attributed by some to God. Time is that which is shown to us as a history of what we did. It reveals our free will and the magnitude of maladies therefrom. Who would not like to be freed from the consequences of their evil actions? We would not believe what was about to occur as the flowing consequences of the choice. The chaos of it all was staggering. We assumed we could never do such things. Yet Time documents and is the evidence of the evils we freely committed; since any and all prohibitions against any expression of free will, no matter how egregious were forbidden. Why focus on our own evils when we can blame someone else? To this end, Augustine notes that men are ready to accuse anything for their sins but themselves ${ }^{115}$. Our self, much of which is described by Hick ${ }^{116}$; is however already complete, yet we forgot how we did it.

As we wandered from God and Gods boundaries we descended to a dark abyss ${ }^{117}$. When we left Omnipotency and the Divine Realm, blinded to our volition, which moved us into our non-God chaos. Augustine thought this chaotic motion themed to disturbance and disorder and was a special event, an anomaly ${ }^{118}$ or perhaps - a "hyper-chaos"119.

The created agent draws others to itself by similarity, likeness or conversion to its own end ${ }^{120}$. Recall that just recently we managed to conduct the great World Wars and Auschwitz and also see Stalin, Mao, King Leopold and the Khmer Rouge in action. These are "illusions"? We are "too immature to fathom" the evils we perpetrate? Are we forced to do what we do? All events in the Great Film called Time are just waiting for our instantiations. We await our time to do our time; our free deeds in our unrecollected time.

Time, the unwinding of the Film in the Divine DVD, is what we do not want to see at all. As Rahner put it; "we do not know how we stand before God but no one can decline his nature and return his ticket"121: which is to say that "we do not know that everything will end well"" Theistic contingency conjectures and statements like "will", "will not", "what might", "what might not" and natural knowledge like "What Could Be" or "Middle Knowledge" "123 are unimportant. All these are irrelevant to God. They are but our imaginings since All is past. There is no reality except what has occurred. Omniscience knows this, we forgot. The proper subject and object of such contingency statements and the multitude of the possible could or could nots are our own musings about our own predictions and predilections i.e., our own forgotten choices.

Leibniz thought that God's foreknowledge renders all the future certain and determined $^{124}$. It is, since Time is our own completed but anamnestically unknown happening in the concluding moment; "currently" recalled but generally forgotten as to how we got 
there. The consequences of our Free Will are reconciled with any notion of Theological Determinism since Omniscience knows our outcomes but displays the unrestricted spectacle we have forgotten to us. The classical account that divine omniscience knows all truths ${ }^{125}$ is maintained, since the anamnestic view of Time is the rewound DVD.

The DVD of our self and the evil we created are complete, but we forgot and forget how we did it. Our Time shows us to ourselves. Evil will end at the end of time; when the film runs out at the eschatological moment. We are finally in total recall at the end.

A Book of Life is written, we do not recall our page number.

\section{CONCLUSION:}

Science and Philosophy have produced a number of longstanding and contrasting viewpoints regarding Time. Many incongruent standpoints in those disciplines present themselves as indicators to substantiate the concept that a new Philosophy of Time is needed and how that thinking impacts our understanding of the problem of evil or Theodicy.

The predominant linear view of time obfuscates our understanding of Time and Evil. The Platonic concept of anamnesis is amended here as the preeminent concept of Time and also how Time as anamnesis pertains to Omniscience and the problem of evil. Time flows backwards not forwards. We are already completed but we unfurl in Time because we have forgotten how we freely chose ourselves. Omniscience knows this; we don't remember and now live that forgetfulness. All is Past, a Book of Life is written, and we forgot our page number.

Acknowledgement: With gratitude to the Hesburgh Libraries, University of Notre Dame, Notre Dame, Indiana.

\section{BIBLIOGRAPHY:}

${ }^{a}$ Presented in part, Frank A. Piontek. Time has Gone Today, $62^{\text {nd }}$ Annual Meeting of the International Society for the Systems Sciences, Oregon State University, Corvallis Oregon; July, 26, 2018.

[1] Inge, William. God and the Astronomers. London: Longmans Press, 1934, p.71.

[2] Wheeler, John Archibald. Hermann Weyl and the Unity of Knowledge. American Scientist, Vol. 74, JulyAugust 1986: Reproduced for weylmann.com. 2004, p24.

[3] Carr, Bernard. Metacosmology and the Limits of Science. In Mathematical Structures of the Universe, (Eds.) M. Eckstein, M. Heller \& S. J. Szybka, Krakow: Copernicus Press, 2014, p408.

[4] Craig, William Lane. Theism and Physical Cosmology. In A Companion to Philosophy of Religion. (Eds.)

C. Taliaferro, P. Draper \& P.Quinn, New York: Wiley-Blackwell. 2010, pp 539-554.

[5] Laszlo, Ervin. System, Structure and Experience. New York: Gordon \& Breach, 1960, p 71.

[6] Ştephan, Florea. The Premises of a Public Dialogue between Science and Religion. International Journal of Theology, Philosophy and Science Vol. 4, No 3. 2019, p5.

[7] Romero, Gustavo Esteban. On the Ontology of Spacetime: Substantivalism, Relationism, Eternalism and Emergence. Foundations of Science, Vol. 22 (1). 2017, p.143.

[8] Plotnitsky, Arkady. Reading Bohr: Physics and Philosophy. The Netherland: Springer, 2006, p.181.

[9] Planck, Max. Where is Science Going? New York: Norton, 1932, p. 217.

[10] Griffin, D. Whiteheadian Physics: Its Implications for Time, Consciousness and Freedom. In Physics and Speculative Philosophy. (Eds.)T. E. Eastman, M. Epperson, \& D. R. Griffin. Berlin: deGruyier, 2016, p.250.

[11] Nagel, Ernest \& Newman, James. Gödel's Proof. New York University Press. 2001, p.5.

[12] Rees, Martin. On the Future. Princeton N.J., Princeton University Press. 2018, p195.

[13] Weyl, Hermann. Mind and Nature. (Ed.) P. Pesic. Princeton University Press. 2009, pp 26-27.

[14] Wheeler, John Archibald. (1996). Time Today. In Quantum Physics, Chaos Theory and Cosmology. (Eds.) M.Namikiet, et al., Woodbury, New York: American Physics Inst. Press.1996, p.46.

[15] Mjaaland, Marius Timmann. Autopsia, Self, Death and God: After Kierkegaard and Derrida. (Trans.) B.McNeal. 2008, p.331. 
[16] Ulanowicz, Robert. Process Ecology. Sophia Vol.55 (3), 2016, p.14.

[17] Verkamp, Bernard J. Thinking about the Laws of Nature. Philosophy \& Theology, \#29 (2), 2017 pp. 397 405 .

[18] Boethius. The Consolation of Philosophy. (Ed.) J. T. Buchanan. New York: Ungar Press, 1957, p.156.

[19] Craig, William. Temporal Becoming and the Direction of Time. Philosophy \& Theology \#11, (2), pp.349-366.

[20] Polkinghorne, John. Exploring Reality. Yale University Press, 2005, p67.

[21] Swinburne, Richard. Is There a God? Oxford UK: Oxford University Press, 1996, p.64-65.

[22] Bergson, Henri. Creative Evolution. A. Miller (Trans.). New York: Hoit \& Co. 1931, p4.

[23] Marsh, Gerald E. Space-Time-Matter. Cornell University Archives. arXiv: 1304.7766, 2013, p.3-5.

[24] Brey, John. Tautological Oxymoron's. Lincoln, Nebraska: Writers Club. 2002, p.59.

[25] Baldwin, John T. God and the World: William Paley's Argument from Perfection Tradition. Harvard Theological Review, 85 (1).1992, p.115.

[26] Baschir, Karim. Potentiality in Natural Philosophy. In Physics and Speculative Philosophy: Potentiality in Modern Science. (Eds.) D. Griffin, M. Epperson \& T. Eastman. Netherlands: De Gruyter, 2016, p.19.

[27] Shimony, Abner. Can the fundamental laws of nature be the results of evolution? In From Physics to Philosophy. (Eds.) J. Butterfield \& C. Pagonis. Cambridge University Press.1999, p.220.

[28] Purcell, Brendan. Dawkins' Fear of Reason. In Human Destinies. (Ed.) Fran O'Rourke. University of Notre Dame Press, Notre Dame, Indiana, 2013, pp.352-3.

[29] Stenger, Victor J. (2009). Quantum Gods. Amherst, New York: Prometheus Books.2009, p.83.

[30] Benci, Vieri. Some remarks on the arrow of Time and the Notion of Information. In Determinism, Holism and Complexity. (Eds.) V. Benci, et al. New York: Kluwer Academic, 2003, p.412.

[31] ibid Wheeler [\#2 above] p.7.

[32] Bennett, Curtis. God as Form. Albany, New York: SUNY, 1976, p.273.

[33] Prudhomme, Jeff Owen. God and Being: Heidegger's Relation to Theology. New York: Humanities Press, 1997, pp.63-68.

[34] Hannah, Robert. Time in Antiquity. New York: Routledge, 2009, p.66.

[35] Aristotle. Physics IV. The Basic Works. (Ed.) R. McKeon, New York: Random House, 1941, pp.289-299.

[36] Plato. (1937). Timaeus Dialogues. Vol. II. B. Jowett, (Trans.), New York: Random House, 1937, p.19.

[37] Plato. Meno Dialogues. Vol. II. B. Jowett, (Trans.), New York: Random House, 1937, p.361.

[38] Plato. Phaedrus Dialogues. Vol. I. B. Jowett, (Trans.), New York: Random House, 1937, 459.

[39] Allen, Richard E. Anamnesis in Plato's Meno and Phaedo. The Review of Metaphysics 13 (1), 1959, pp.165-174.

[40] Gale, Richard M. The Language of Time. London: Routledge.1968, pp.9-16.

[41] Rogers, Katherin. Defending the Isotemporal Solution to the Freedom/Foreknowledge Dilemma: Response to Rhoda. In Debates in the Metaphysics of Time. N.L. Oaklander, (Ed.), London: Bloomsbury, 2014, p.277-280.

[42] Sprigge, Timothy. The Importance of Subjectivity: Selected Essays. In Metaphysics and Ethics. L. B. McHenry (Ed.), Oxford UK: Clarendon Press, 2010, p.11.

[43] Sharpe, Kevin \& Walgate, Jonathon. The Flow of Time: Scientific and Theological Perspectives. Philosophy \& Theology: 13 (2) 2011, p.330.

[44] McTaggert, J.E. (1908). The Unreality of Time. Mind: A Quarterly Review of Psychology and Philosophy, 17 1908: pp.456-473. http://www.ditext.com/mctaggert/time/html.

[45] Meillassoux, Quentin. After Finitude. London: Continuum Press, R. Brassier (Trans.), 2008, pp.35-64.

[46] Massey, Heath. The Origin of Time: Heidegger and Bergson. Albany, New York: SUNY, 2015, p.98.

[47] O'Meara, Thomas F. God in the World. Collegeville, Minnesota, Liturgical Press, 2007, p.72.

[48] Augustine of Hippo. The Confessions of St. Augustine. J. Pilkington, (Trans.), New York: Horace Liveright, Book XI. 1927, pp.285-286.

[49] Hammer, Espen. Philosophy and Temporality: From Kant to Critical Theory. Cambridge U. Press, 2011, p.79.

[50] Plotinus. Complete Works. K.S Guthrie (Trans.), London: George Bell \& Sons, 1918, p.343.

[51] Von Bertalanffy, Ludwig. Perspectives on General System Theory. New York: Braziller, 1975, pp. 6163.

[52] Kant, Immanuel. Religion Within the Limits of Reason Alone. (Trans.), T.M. Greene \& H.H. Hudson. New York, Harper, 1960, p.70.

[53] Matthews, Bruce. Shelling's Organic Form of Philosophy. Albany, New York: SUNY, 2011, pp. 205216. 
[54] Heidegger, Martin. Being \& Time. (Trans.), J. Macquarrie \& E. Robinson San Francisco: Harper, 1962 , p. 447 .

[55] Low, Douglas. Merleau-Ponty in Contemporary Context. New Brunswick, NJ: Action Pub. 2013, pp.5457.

[56] Vass, George. A Theologian in Search of a Philosophy. London: Sheed-Ward. 1985, p.98.

[57] McCall, Storrs. A Model of the Universe. Oxford UK: Clarendon. 1994, p.195

[58] ibid Augustine [\#48 above] p.236.

[59] Hoitenga, Dewey J. Faith and Reason from Plato to Plantinga. Albany, New York: SUNY, 1991, p.76.

[60] Whitehead, A.N. The Harvard Lectures of 1924-1925. (Eds.) P. Bogaard \& J Bell, Edinburgh U. Pres. 2017, p.29.

[61] Pannenberg, Wolfhart. Theology and the Kingdom of God. Philadelphia: Westminister Press. 1969, p.127.

[62] Wolfson, Elliot R. Language, Eros, Being. New York: Fordham University Press. 2005, p.XX.

[63] ibid Weyl [\#13 above], p.32.

[64] Leftow, Brian. Time and Eternity. Ithaca, New York: Cornell University Press, 1991, p.360.

[65] ibid Augustine [\#48 above] p.295.

[66] Rindler, Wolfgang. Gödel, Einstein, Mach, Gamow and Lanczos: Gödel's Remarkable Excursion into Cosmology. In Kurt Gödel and the Foundation of Mathematics. (Eds.) M.Baaz, et al. Cambridge University Press. 2011, pp. 185-186.

[67] Raschke, Carl A. The Interruption of Eternity. Chicago: Nelson-Hall. 1980, pp.139-140.

[68] Pannenberg, W. Metaphysics and the Idea of God. P. Clayton, (Trans), Grand Rapids, Eerdmans. 1988, p.VIII.

[69] Pekarske, Daniel T. Abstracts of Karl Rahner's Theological Investigations 1-23. Philosophy \& Theology 14, (1\&2), 2002, pp. 375-376.

[70] Beran, Ondřej. Misunderstanding the Talk of the Divine: Theodicy in the Wittgensteinian Tradition. Sophia, 56. \#2, 2017, p.184.

[71] Hume, David. Dialogues Concerning Natural Religion. H. D. Aiken, (Ed.), New York: Hafner,1951, p.66.

[72] Silvestre, Ricardo Sousa. On the Concept of Theodicy. Sophia, 56 \#2, 2017, p.208.

[73] Bobier, Christopher Allan. God, Time and the Kalan Cosmological Argument. Sophia V.52. \#4, 2013, p.593.

[74] Ricoeur, Paul. Evil. J. Bowden, (Trans.), New York, Continuum Press. 2007, p.13.

[75] Surin, Kenneth. Theodicy? Harvard Theological Review, \#76 (2), 1983, pp.225-230.

[76] Davies, Horton. The Vigilant God. New York: Lang Publishers, 1992, p.1.

[77] DiCenso, James C. A Commentary on Kant's Religion Within the Limits of Reason. Cambridge U. Press, 2015, p.39.

[78] Barmeau, Maurice. The Theodicy of Alfred North Whitehead. Lanham, Maryland: University Press of America, 1991, pp.182-83.

[79] Royce, J. Metaphysics. (Eds.)W. Hocking, R. Hocking and F. Oppenheim. Albany, NY. SUNY, 1998, p.277.

[80] Swinburne, Richard. Providence and the Problem of Evil. Oxford UK: Oxford University Press,1998, p.X.

[81] Massimo, Giuliani. Theological Implications of the Shoah. New York: Lang Publishers, 2002, p.59.

[82] ibid Surin [\#75] p.230.

[83] Galbraith, Elizabeth C. Kant and a Theology of Protest. In Kant and the New Philosophy of Religion. (Eds.) C. Firestone \& S.R. Palmquist . Bloomington, IN: Indiana University Press. 2006, pp.179-181.

[84] Phillips, D.Z. The Problem of Evil \& The Problem of God. Minneapolis, Fortress Press, 2005, p.109.

[85] Schellenberg, J.L. Divine Hiddenness and Human Reason. Ithaca, New York: Cornell U. Press. 1993, pp.1-2.

[86] Spinoza, Benedict de. Ethics. (Trans. E. Curley). New York: Hafner Publishing, 1949, pp.233-234.

[87] Mander, William. The Unreality of Evil. Sophia Vol. 57, (2), 2018, p.249.

[88] Yousif, Alex. The Undeniable Reality of Evil: A Response to W.J. Manders. Sophia Vol. 57 (3), 2018, p.519.

[89] Adams, Marilyn M. Horrendous Evils and the Goodness of God. In The Problem of Evil. (Eds.) M.M. Adams \& R.M. Adams Oxford UK: Oxford University Press, 1990, p.217.

[90] Nietzsche. Thus Spake Zarathustra. (Trans.), T. Common, New York: Macmillan, 1924, p.105.

[91] ibid Meillassoux [\#45] p.35. 
[92] ibid Silvestre [\#72] p207.

[93] Peterson, Michael L. (Ed). The Problem of Evil. Notre Dame Press: Notre Dame, Indiana, 2017.

[94] Herman, Arthur L. The Problem of Evil and Indian Thought. Delhi, India: Motilal Publishers. 2000.

[95] Flescher, Andrew Michael. Moral Evil. Washington, D.C.: Georgetown U. Press. 2013.

[96] Meister, Chad \& Taliaferro, Charles. (Series Eds.), The History of Evil. New York: Routledge. 2018.

[97] Marion, Jean-Luc. The Impossible for Man-God. In Transcendence and Beyond. (Eds.) J.D. Caputo \&

M. J. Scanlon, Indiana University Press, 2007, p.20.

[98] ibid Rodgers [\#41].

[99] Leibniz. Theodicy. E.M. Huggard, (Trans), Yale University Press, 1952, p.124.

[100] DeRoo, Neal. The Weakness of God. In Cross and Khôra: Deconstruction and Christianity in the World of John D. Caputo. (Eds.) M. Zlomislic \& N. DeRoss. Eugene OR: Pickwick Publishing, 2010, p.314.

[101] Bugiulescu, Marin. Philosophy and Theology, Science and Knowledge, Truth and Life. International Journal of Theology, Philosophy and Science, Vol. 1, No.1, 2017, p.5.

[102] Bugiulescu, Marin. Ontology and Metaphysics: Being and Person- God and Man. International Journal of Theology, Philosophy and Science, Vol. 4 No.3.2019, p.67.

[103] Plantinga, Alvin. God and Other Minds. Ithaca, New York: Cornell U. Press, 1967, p.132.

[104] Choo, Frederick. and Goh, Esther. The Free Will Defense Revisited: The Instrumental Value of Significant Free Will. International Journal of Theology, Philosophy and Science, Vol. 4, \# 3, 2019, pp. 3245.

[105] Roberts, Louis. The Achievement of Karl Rahner. New York: Herder \& Herder, 1967, pp.207-208.

[106] Leftow, Brian. Instants, Events and God. In Debates in the Metaphysics of Time. N. L Oaklander. (Ed). London: Bloomsbury, 2014, p.245.

[107] Flew, Antony. There is a God. New York: Harper One, 2007, p.152.

[108] Koperski, Jeffery. The Physics of Theism. New York: Wiley Blackwell, 2015, pp.138-139.

[109] ibid. Leftow [\#64] p.360.

[110] Moltmann, Jürgen. Science and Wisdom. M. Kohl (Trans.), Minneapolis: Fortress Press, 2003, p.80.

[111] ibid. Polkinghorne [ \#20] p.139.

[112] ibid. Phillips [\#84] p.109.

[113] Müller, Julius. The Christian Doctrine of Sin Volume 1. W. Urwick, (Trans.), Edinburgh: Turnbull \& Spears, 1868, p.193.

[114] Hunt, David. The Simple-Foreknowledge View. In Divine Foreknowledge. (Eds.) J. K. Bielby \& P.R. Eddy, Downers Grove, IL: InterVarsity Press, 2001, p.75.

[115] Scott, Mark S. M. Pathways in Theodicy. Minneapolis: Fortress Press, 2015, p.69.

[116] Hick, John. Death and Eternal Life. Louisville KY: John Know Press, 1994, pp.35-53.

[117] ibid. Müller [\#113] p.215.

[118] Evans, Gillian R. Augustine on Evil. Cambridge UK: Cambridge U. Press, 1982, p.94

[119] Phelps, Hollis. Absolute Power and Contingency: On the Theological Structure of Meillassoux's Speculative Philosophy. Sophia Vol.54, \#3, 2015, p.343.

[120] Aquinas. On Evil. J. Oesterle, (Trans.), Notre Dame, Indiana: Notre Dame Press, 1995, p.105.

[121] Pekarske, Daniel T. Abstracts of Karl Rahner's Unserialized Essays. Milwaukee: Marquette U., 2009, p.453.

[122] Rahner, Karl. Theological Investigations Volume 3. Karl H. \& B. Kruger, (Trans.), Baltimore: Helicon Press, 1967, p.149.

[123] Hess, Elijah. The Open Future Square of Opposition: A Defense. Sophia Vol.56 \#4, 2017, pp. 573-587.

[124] ibid. Leibniz [\#99] p.124.

[125] Byerly, T. Ryan. Restricted Omniscience and Ways of Knowing. Sophia Vol. 53 \#4, 2014, p.427. 